\title{
El editorial
}

La revista Desarrollo gerencial se ha caracterizado por la divulgación de los resultados de la labor investigativa producida por las instituciones de educación superior las cuales presentan un carácter multidisciplinar con proyección internacional comprobable en los rankings y bases de datos internacionales la publicación de la revista ha sido posible por la conjunción de los esfuerzos de investigadores académicos comprometidos en la calidad e impacto de los resultados en el entorno.

En este marco Desarrollo gerencial ha venido actuando como un instrumento clave en la organización, vertebración e institucionalización social de temas específicos de una disciplina o área de conocimiento en especial de las ciencias económicas, administrativas y contables teniendo en cuenta la relación que mantiene esta disciplina con las demás y con la sociedad. Es así como en esta publicación el lector se encontrará con diversas temáticas de interés para el sector educativo y para los sectores de construcción, calzado y turismo

Entre los artículos dirigidos al sector educativo se encuentra el modelo de acreditación por alta calidad en programas académicos universitarios en Colombia cuyo objetivo fue conocer la percepción de dos grupos de expertos representados por pares y los directivos académicos que han participado en procesos de esta naturaleza. Los resultados obtenidos permitieron conocer que pese a que los 
expertos tienen una percepción positiva del modelo de acreditación y de sus factores, también piensan que es indispensable revisarlo y contemplar cambios en su estructura debido a que los factores incluidos en el modelo fueron considerados extensos y descontextualizados al responder más a las orientaciones de organismos externos que a las necesidades propias de la calidad en un programa académico. De igual forma los investigadores interesados por la consecución de la calidad laboral en las universidades presentan un articulo denominado satisfacción laboral y el clima organizacional de las principales universidades sucreñas el cual tuvo como objetivo describir los elementos que conforman la satisfacción laboral y determinar cómo este factor influye en el clima organizacional de los empleados; Los resultados evidenciaron que no hay suficiente apoyo para el crecimiento profesional y que las capacitaciones son escasas. Otra de los estudios realizados en las instituciones educativas se relacionó con el uso de las TICs en la gestión del conocimiento por parte de la universidad de Zulia Venezuela En esta investigación se hace evidente la importancia de las TICs en el proceso de enseñanza- aprendizaje y de manera concreta; ante este nuevo reto la percepción de los estudiantes y docentes se convierte en un importante elemento de estudio.

Pero aparte del tema educativo los investigadores han estudiando otros sectores como el de confección el artículo pertinente tuvo como objetivo identificar factores de naturaleza no monetarios asociados a las Pymes del sector Confecciones que afectan su ingreso a mercados Internacionales en esta investigación se observó 
la ausencia de modelos de gestión empresarial innovadores tales como el clúster, asociaciones, y cadenas de suministros. Las conclusiones se enfocaron en cuestiones relacionadas con la competitividad del sector y en la proyección de la exportación, Para el éxito de estos acometidos se hace necesario el monitoreo de los indicadores de competitividad que los empresarios consideraron como elementos clave para el sector de la confección.

El lector tendrá la oportunidad de conocer además una investigación bibliográfica cuyo objetivo fue diagnosticar la situación actual, en materia de asociatividad empresarial en el municipio de Sincelejo (Colombia), Los resultados evidenciaron que, en este municipio el estado de asociatividad empresarial es bastante precario o nulo, al no pertenecer buena parte de las empresas a ninguna asociación, ni tener noticias de la existencia de alguno de estos entes. Se concluye en consecuencia que no se evidencian estrategias de apoyos a la micro y pequeña empresa productora de calzado del municipio por parte del Estado, que fomenten su desarrollo productivo y las impulsen hacia la competitividad. Pues resulta evidente que hoy día en el escenario de la globalización la asociatividad y el cooperativismo se han convertido en una estrategia competitiva fundamental.

De igual forma se realiza una revisión bibliográfica del sector construcción en el mismo municipio. En este caso el objetivo consistió en mostrar las estrategias que utilizan las empresas de la construcción, en la ciudad de Sincelejo (Sucre), Colombia, para la generación de ventaja competitiva. Para ello, se consultaron, aproximadamente, 60 fuentes secundarias entre Journals, revistas científicas 
indexadas, libros físicos y electrónicos de diferentes autores e investigaciones relativos a la temática planteada. Posteriormente, se realizó un análisis, obteniéndose como resultado las diferentes estrategias utilizadas por las empresas del sector de la construcción, para lograr ventaja competitiva.

Fundamentados en las debilidades de los sectores económicos con respecto al cooperativismo el siguiente articulo expone unas consideraciones teóricas sobre estrategia y gestión en el contexto de las cooperativas. La estrategia es una poderosa herramienta que facilita la gestión así como la gestión es un elemento decisivo para la ejecución de la estrategia, Se muestra claramente que ambos elementos se constituyen en un proceso de renovación abierto y articulado con los retos del entorno.

Para finalizar la edición no podría hacer falta considerar los modelos de gestión eco turísticos, tema de gran interés competitivo para los países en vía de desarrollo como Colombia, este artículo tuvo como objetivo analizar el entorno competitivo del proyecto eco turístico en el corregimiento de Galerazamba, adscrito al municipio de Santa Catalina (Bolívar, Colombia). El recorrido teórico plasmó temas de la planeación estratégica hasta llegar a los conceptos de modelos de negocios más promisorios para aplicar. Los resultados obtenidos, ayudaron al establecimiento de una propuesta de valor integradora para el proyecto, basada en el modelo planteado por Osterwalder. Se concluye que el proyecto es viable si se integra diferentes modalidades de servicios permitiéndoles 
a los turistas de diferentes segmentos, encontrar en un solo lugar diferentes productos y servicios.

Invitamos pues a todos los lectores a consultar y referenciar en sus investigaciones y publicaciones los artículos de esta edición, para abrir espacios de debates y discusiones en el área de las ciencias económicas, administrativas y contables. 


\section{EDITORIAL}

The scientific journal Desarrollo Gerencial has been characterized by the publication of the results of the research work of multidisciplinary character, which is produced by higher education institutions. The international projection of the publication can be verified in the rankings and international databases; and all this has been possible for the conjunction of the efforts of academic researchers committed to the quality and impact of the results in the environment.

In this frame, Desarrollo Gerencial has come operating like a key instrument in the organization, structure and social institutionalization of specific topics of a discipline or area of knowledge, especially of the economic, administrative and countable sciences, bearing in mind the relation that this discipline keeps with the others and with the society. In this publication, the reader will meet diverse subject-matters of interest for the educational sector, as well as the construction, footwear and tourism sectors.

Among the articles directed to the educational sector, the model of accreditation stands out for its high quality in academic university programs in Colombia, whose aim was to know the perception of two groups of experts represented by pairs and the academic directors who have taken part in processes of this nature. The results obtained allowed to know that although the experts have a positive perception of the model of accreditation and its factors, they think that it is imperative to revise it and to envisage changes in its structure. According to the aforementioned experts, 
the problem is that the factors included in the model were extensive and out of context, and they respond more effectively to the orientations of external organisms than to the proper needs of quality in an academic program.

Similarly, other researchers interested in the attainment of labor quality in the universities, present an article named labor satisfaction and the organizational climate of the principal universities in Sucre, whose main objective was to describe the elements that shape the labor satisfaction and to determine how this factor influences the organizational climate of the employees. The results demonstrated that there is no sufficient support for professional growth and that trainings are scarce.

Other studies carried out in the educational institutions was about use of the ICT in the management of knowledge by the Universidad de Zulia in Venezuela. In this research the importance of the ICT in the process of education-learning becomes clear and, in a concrete way, before this new challenge, the perception of the students and teachers turns into an important element of study. But apart from the educational topic, the researchers have studied other sectors as that of the clothing. The article aimed to identify non-monetary factors associated with Small and Medium-sized Enterprises (Pymes) of the clothing sector that affect his revenue to international markets. In this research, the absence of innovative models of managerial management such as the cluster, associations, and supply chains. The conclusions focused on issues related to the competitiveness of the sector and in the projection of the exportation. For the success of these 
enterprises, it is necessary the monitoring of the indicators of competitiveness that the businessmen considered to be key elements for the clothing sector.

The reader will have the opportunity to know, also, a bibliographical research, whose target was to diagnose the current situation, on the subject of partnerships in the municipality of Sincelejo (Colombia). The results demonstrated that, in this municipality, the state of business partnerships is quite precarious or void, since a large number of the companies are not part of any association. It is concluded, consequently, that there are not strategies of support provided by the State to the micro and small enterprises of footwear in the municipality, which foster their productive development and springboard them onto competitiveness; since, it turns out to be clear that today, in the stage of the globalization, partnership and cooperativism have turned into a fundamental competitive strategy.

Likewise, a bibliographical review of the construction sector in the same municipality was carried out. In this case, the objective was to show the strategies used by the companies of the construction in the city of Sincelejo, Sucre, in Colombia, to generate competitive advantage. For it, 60 secondary sources were consulted, approximately, including Journals, scientific indexed journals, and physical and electronic books of different authors and researchers regarding the raised subject-matter. Subsequently, an analysis was conducted, resulting in the different strategies used by the companies of the construction sector, in order to achieve competitive advantage. 
Based on the weaknesses of the economic sectors with regard to the cooperativism, the following article presents a few theoretical considerations on strategy and management in the context of the cooperatives. The strategy is a powerful tool that enables the management, as well as the management is a decisive element for the execution of the strategy. Thus, it reports clearly that both elements are constituted in a process of renewal open and articulated with the challenges of the environment.

To finish the edition, it is necessary to consider the management models of echo tourism, which is a topic of great competitive interest for the countries in route of development as Colombia. This article aimed to analyze the competitive environment of an eco tourist project developed in the corregimiento of Galerazamba, under the jurisdiction to the municipality of Santa Catalina (Bolivar, Colombia). The theoretical trip captured topics of the strategic planning up to coming to the most promissory concepts of business models to apply. The results obtained helped to the establishment of an integrative proposal of value for the project, based on the model raised by Osterwalder. It is concluded that the project is viable if different forms of services are integrated, allowing the tourists of different segments to find different products and services in one place.

We invite all readers to consult and reference in their research projects and publications the articles of this edition, to create spaces for debates and discussions in the field of the economic, administrative and countable sciences. 